
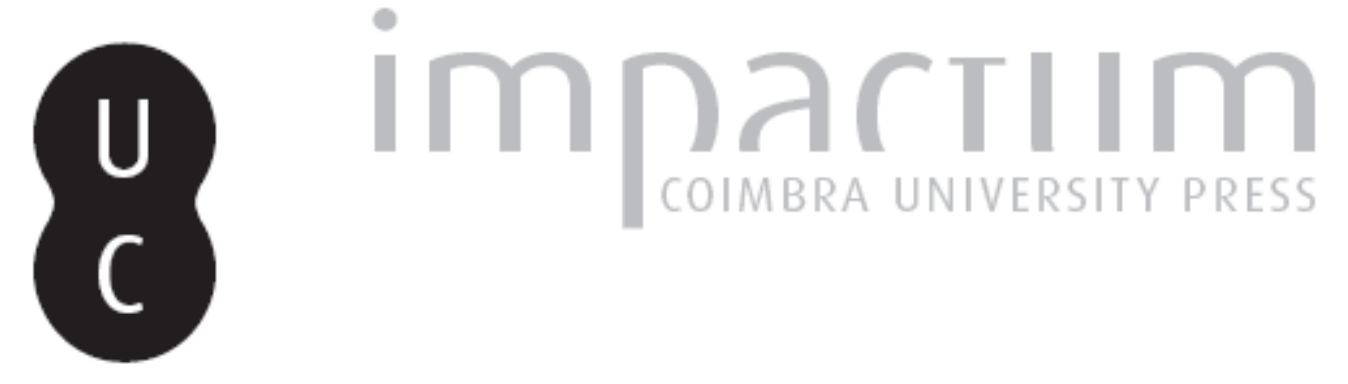

\title{
As rinhas de galo como exercício para a postura da Persona trágica
}

Autor(es): $\quad$ Barbosa, Tereza Virgínia Ribeiro

Publicado por: Faculdade de Letras da Universidade de Coimbra

URL persistente:

URI:http://hdl.handle.net/10316.2/32743

DOI:

DOI:http://dx.doi.org/10.14195/0870-4112_7_11

Accessed : $\quad$ 26-Apr-2023 16:33:40

A navegação consulta e descarregamento dos títulos inseridos nas Bibliotecas Digitais UC Digitalis, UC Pombalina e UC Impactum, pressupõem a aceitação plena e sem reservas dos Termos e Condições de Uso destas Bibliotecas Digitais, disponíveis em https://digitalis.uc.pt/pt-pt/termos.

Conforme exposto nos referidos Termos e Condições de Uso, o descarregamento de títulos de acesso restrito requer uma licença válida de autorização devendo o utilizador aceder ao(s) documento(s) a partir de um endereço de IP da instituição detentora da supramencionada licença.

Ao utilizador é apenas permitido o descarregamento para uso pessoal, pelo que o emprego do(s) título(s) descarregado(s) para outro fim, designadamente comercial, carece de autorização do respetivo autor ou editor da obra.

Na medida em que todas as obras da UC Digitalis se encontram protegidas pelo Código do Direito de Autor e Direitos Conexos e demais legislação aplicável, toda a cópia, parcial ou total, deste documento, nos casos em que é legalmente admitida, deverá conter ou fazer-se acompanhar por este aviso.

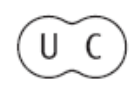




\section{Sociedade em Tumulto}

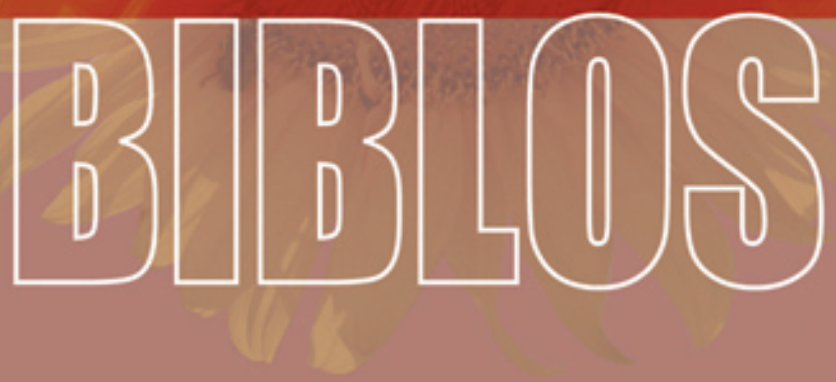

REVISTA DA FACULDADE DE LETRAS

UNIVERSIDADE DE GOIMBRA 
Biblos, n. s. VII (2009) 243-260

Tereza Virgínia Ribeiro Barbosa

Universidade Federal de Minas Gerais

\section{AS RINHAS DE GALO COMO EXERCÍCIO PARA A POSTURA DA PERSONA TRÁGICA}

\section{Resumo}

Neste trabalho, pretendemos comentar a postura que se poderia esperar de um actor trágico no desempenho da sua função, a saber, a representação do homem tal como o entendia a sua época, o século V a.C. A nossa meta será limitada, ao fazer o comentário e tirar conclusões sobre um galo, animal ilustre que figurou em obras literárias de povos do mundo inteiro. Exemplos não faltam e, entre eles, destacamos uma metáfora de Ésquilo para designar o notável Egisto, amante de Clitemnestra, que desempenha, na tragedia Agamemnon, um papel coadjuvante no assassinato do rei vencedor da guerra de Tróia, seu primo.

Palavras-chave: actor trágico, metáfora, representação.

\section{Abstract}

The purpose of this article is to discuss the posture expected of the tragic actor in his performance, namely the representation of man as he was viewed in the 5th century B.C. The goal is limited to the commentary and discussion of the figure of the cock, a famed animal that appeared in literary works throughout the world. Among the many examples that abound, the article highlights Aeschylus's metaphor for the notable Aegisthus, Clytemnestra's lover, who plays the role of coadjuvant in the assassination of his cousin, the king who won the Trojan war, in the tragedy Agamemnon.

Keywords: tragic actor, metaphor, representation.

O que resta do teatro grego, excetuando testemunhos iconográficos em cerâmica - dentre os quais alguns bem incertos - e a monumental construção dos teatros sobreviventes é, basicamente, só o que foi escrito. Esses escritos, como cadáveres embalsamados, preservaram corpos que, por séculos, vêm atuando ora de modo eficaz, ora de forma grotesca e assustadoramente anacrônica. 
Isso se dá, no nosso entender, porque notações impressas são complexas. Elas revelam e ocultam tudo o que nelas há e por isso possibilitam ao mesmo tempo sucessos e fracassos. De ordinário, um intérprete-tradutor de teatro, seja ele stricto sensu, seja ele intersemiótico, enfrenta problemas terríveis na tentativa de preservar um suposto original para leitura, ou, quiçá, para encenação. A compreensão do que se lhe apresenta complica-se ainda mais no caso de peças teatrais, quando o texto sozinho não se basta e pressupõe signos não-lingüísticos para entendê-lo.

Donald Lateiner dedicou um livro inteiro - Sardonic Smile (Ann Arbor, University of Michigan Press 2001) cuja primeira edição data de 1998 - a investigar e ensinar a leitura do comportamento não-verbal na épica de Homero. Nessa obra ele retira da Ilíada e da Odisséia toda uma partitura de comportamentos (gestos, posturas, variação de tons na elocução, modulações vocálicas, percepção e manipulação do tempo e espaço, etnogestos etc.) para mostrar e até mesmo visualizar a performance das personagens nos poemas. Segundo ele, em cada textopersonagem perpassam mensagens que o situam, definem e qualificam como um corpo em ação.

Embora trate especificamente de Homero, essa obra será uma referência de base para nós. Não vamos buscá-la pontualmente, mas aplicamos em nosso estudo o método de leitura do helenista americano que, por sua vez, se baseia nos estudos lingüísticos do britânico John Austin em Quando dizer é fazer (Porto Alegre, Artes Médicas 1990) esse último, um tanto ultrapassado contudo ainda útil e operativo. Deles tomaremos o pressuposto de que o texto escrito registra comportamentos não-verbais que falam para nossos olhos: D. Lateiner Sardonic Smile (Ann Arobr, University of Michigan Press 2001) 3 e de que o dizer determinadas palavras é, na verdade, um fazer: J. Austin Quando dizer é fazer (Porto Alegre, Artes Médicas 1990) 26.

O texto teatral, sobretudo aquele das tragédias gregas, nosso objeto primeiro de investigação, é um gênero particular que conta em grau maior, digamos antes que converge, visceralmente, para os gestos, movimentos e metáforas (neles inseridos a modo de didaskáliai) de corpos escritos os quais, para sobreviverem materialmente (e nisso estamos pensando especialmente em um teatro encenado com sua corporeidade orgânica) necessitam tornar-se corpos em animação. Apenas assim, as figuras míticas, conservadas por aromas poéticos e balsâmicos, saltam de pergaminhos, papiros e papéis como se fossem vivas diante do ator-leitor-espectador. 
Nesse processo, a saber, no teatro encenado (se o tomamos em princípio como texto apenas), o ator funciona como o principal tradutor da letra que ele mesmo leu (seja em grego ou qualquer outra língua) e compreendeu. Ele deve traduzi-la em seu corpo, em sua voz, em sua performance e, para tanto, sem dúvida fará uso de registros textuais indicadores de comportamentos que se tornam formas de agir.

Desse modo, podemos recorrer a Walter Benjamin ${ }^{1}$ e emprestar dele a expressão "A tradução é uma forma". Diríamos, baseados no filósofo alemão, que o ator-tradutor busca uma forma física para traduzir um original escrito, fonte de todas as suas ações em cena. De fato, nos séculos V e IV a.C., o ator é chamado hipokrités, ou seja, o que responde ou o que interpreta presságios ou sonhos. O significado específico de 'ator' ocorre, segundo A. Pickard-Cambridge ${ }^{2}$, já em Píndaro e mais tarde em Aristóteles. Um escólio, para o verso 148 do Agamemnon de Ésquilo, nomeia os integrantes do coro como hypokritaí. O termo nos é oportuno, pois engloba tanto o sentido de responder, quanto o de atuar e ainda o de interpretar, em nosso contexto aqui ampliado por traduzir. ${ }^{3}$

Assim sendo, o ator grego traduz o material escrito e utiliza-se dele para estabelecer sua lei comportamental: o seu modo de andar, virar-se, mover a cabeça, respirar, colocar sua voz. E por esse raciocínio perguntamo-nos: a partir dos textos remanescentes, como um ator que pretende corporificar uma personagem trágica ocupa o espaço da cena? Como andaria um Agamémnon, um Édipo, uma Jocasta? Como entrar e sair de cena? Que leveza ou gravidade imprimir em seu andar? Como mover a cabeça, lentamente, solenemente? E o respirar deve ser controlado? Qual o tom de voz? E sua postura? Triunfante? Instável? Resoluto? Fracassado?

Tais interrogações não são inadequadas. Estamos investigando uma arte mimética que se constrói - para além das formas que comporão o seu papel antes escrito - de gestos, cores e espaços preenchidos. Nesse tipo de arte o ato almeja ser visto e visto como arte. Em tais circunstâncias até mesmo o feio será apresentado de forma tecnicamente medida para causar um efeito planejado.

${ }^{1}$ Servimo-nos da tradução de Susana Kampff Lages para o ensaio A tarefarenúncia do tradutor, publicado nos cadernos Viva Voz da Faculdade de Letras da Universidade Federal de Minas Gerais www.letras.ufmg.br/site/publicacoes/.../ tarefadotradutor-site.pdf

${ }^{2}$ The dramatic festivals of Athens (Oxford, Clarendon Press 1968) 126-127.

${ }^{3}$ Privilegiamos o termo hypokrités em lugar de tragoidós. 
E o efeito mais interessante, aquele que nos permite ver o belo e o feio, o bom e o mau, o moral, o imoral e o amoral pode ser um só, a saber, a sensação de reconhecer. A informação é de Aristóteles (Poética 1448b 19) e de Plutarco (De aud. poet. 18a-c). Segundo eles, o artista deve mostrar correspondências e semelhanças suficientes para despertar em seu público o prazer de um reconhecimento. Dessa forma, ele pode criar, de forma conveniente, uma bela imagem a partir de um corpo feio. No mesmo passo citado, Plutarco comenta a diferença entre ouvir um porco guinchar (ou o ranger de uma roldana, o assobio do vento, o estrondo do mar e todo o tipo de barulhos desagradáveis) e escutar (e ver), no teatro, Parmenon, como um porco, ou Teodoro imitando o ringir das roldanas. Fugimos de um doente e contemplamos com gosto as chagas de um sofredor em um espetáculo, evitamos um corrupto e rimos de suas vilezas em cena.

É nesse ponto que acreditamos poder contribuir, de algum modo, com a indicação de uma postura para o ator de um hybristés. Cremos que existem comportamentos não-verbais, indicados nos textos de teatro grego que, por eles mesmos, constituem um acesso eficaz ao trágico. ${ }^{4}$ São gestos e movimentos sugeridos para mostrar a tensão e a aporía de um corpo que age. Sem dúvida, tais passagens facilitam o entendimento do texto. De resto, buscar os tais comportamentos nãoverbais na partitura escrita pelos dramaturgos é uma forma orgânica de guardar a vida do original.

Desse modo, a tradução no corpo do ator tenderia a expressar o mais íntimo relacionamento entre o homem grego e o homem contemporâneo, de forma a apresentar ações análogas, manifestas no passado e no presente, registradas em formas linguísticas que, entretanto, ultrapassassem o linguístico. A base de tudo isso é que homens não são, de todo, estranhos uns aos outros. Talvez o corpo, abstraindo as circunstâncias históricas, seja o lugar onde encontraremos afinidade entre a escritura grega para a cena e a contemporânea.

Uma obra escrita no mundo antigo que em sua realização espetacular tem um corpo que deve agir frente a um auditório sob regras codificadas, esse é, portanto, o nosso tema. Muitos serão os códigos que o ator pode tomar para representar seu papel. Nesse artigo vamos

${ }^{4}$ Propomos um sentido muito largo para 'trágico', a saber, não conhecer sua própria medida, desafiar um antagonista maior por falta de discernimento (áte) e engendrar a própria desgraça. 
contemplar somente um conjunto de ações que se poderá organizar para comportar-se - na cena - como um homem trágico.

Comecemos pela voz. O ator trágico, além de bailarino, é também um cantor. Ele deve saber tanto a arte da dança quanto a do canto ${ }^{5}$ para criar na cena um mundo sensível e visível para o espectador. É a partir do mesmo helenista britânico, citado há pouco, A. Pickard-Cambridge ${ }^{6}$, que sabemos que a apresentação de uma peça - para atores e coreutas - envolve três elementos: elocução do texto, gestos e movimentos (de entradas e saídas de um lugar para outro). O exercício de tudo isso inclui o diálogo, o discurso acompanhado por melodia (recitativo) e o canto. Ao que tudo leva a crer (ibidem 167, 170), para a audiência antiga era de suma importância a voz do ator e a clareza na enunciação. O vocabulário é vasto, mas dentre eles citamos a megalophonía (magnificência de voz); a euphonía (beleza ou vigor de voz) e a lamprótes (brilho ou clareza de voz). A sensibilidade da audiência exigia não somente boa voz, mas clareza e correção na enunciação. Uma famosa anedota de Aristófanes dá a medida do rigor. Em Rãs, 303, o comediógrafo faz referência a um tal de Hegéloco o qual teria pronunciado, equivocadamente, para o verso 279 de Orestes, a palavra galên (doninha) com acentuação longa, por galén (calmaria) com acentuação breve.

Também segundo G. Capone, esperava-se apuração na técnica vocal, quer para falar continuamente num fôlego só (ê̂rai apotáden, apneustî), quer para uma recitação simples (katalogé), uma dicção melodramática (parakatalogé) ou um canto (mélos). A importância da voz para o hypokrités, é, segundo o italiano, inquestionável.

Alla base della parola greca designante l'attore, presa in senso stretto, c' è dunque la funzione fondamentale del parlare, del rispondere. La parola si manifesta mediante la voce: a seconda della tonalità, dell' inflessione di voce, si colorisce variamente il discorso. Molteplici doti di voce erano richieste all'atore greco, per le esigenze a cui egli doveva soddisfare: chiarezza, per la vastità del teatro, mobilità, duttilità, dovendo

${ }^{5}$ As referências aqui coletadas foram tomadas de G. Capone, L'Arte scnica degli attori tragici greci (Padova 1935) 112-120. Sobre o canto (tò mélos) Aristóteles, Poética 1447b, 25; para a arte da dança: Políbio IX, 20, 7; Luciano, Sobre a dança 65, 71. Sobre a dança trágica (emméleia) Platão, Leis 816b, Luc. Sobre a dança 22, 26; sobre as figuras de dança (tò schêma) Platão, Leis 669d., Aristófanes, Vespas 1485. Capone fornece um repertório vasto de termos técnicos na terminologia teatral antiga.

${ }^{6}$ The dramatic festivals of Athens (Oxford, Clarendon Press 1968) 156. 
rappresentare anche parti di donna (Luc. De salt., 28) e spesso personaggi diversi nello stesso drama; rapidità di modulazione, nel passaggio tra parti recitate, melodramatiche e cantate.

Oltre a queste particolari condizioni, la voce doveva rispondere alla diversa età dei personaggi rappresentati, e passare istintivamente per la gamma naturale di toni e sfumature rispondenti a toni e sfumature di stati d' animo. ${ }^{7}$

Há, portanto, um trabalho sobre o corpo e sobre a voz do ator. Todavia, insistimos, para o artista, o material do cotidiano é sempre modificado tecnicamente de modo a não se manifestar como natural, mas como um código que evoca o real. O corpo e a voz do ator trágico seriam trabalhados a fim de que as questões de dicção e interpretação parecessem naturais, o que sabemos, não o são.

"A gramática complexa do corpo feita de carne e de sangue, de humores e odores, nos coloca frente à justeza, quer dizer, frente ao nosso justo lugar no mundo da cena;"8 e da cena o ator deve comunicarse com seu público de maneira planejada. Sua dança e seu canto tornam visíveis os valores contidos no texto poético, no nosso caso, o valor do trágico. E, se pretendemos falar sobre os dramas trágicos gregos, sobre a solenidade e nobreza atribuídas ao gênero e consagradas por Aristóteles, se pretendemos visualizar uma das posturas que se poderia esperar de um ator trágico cantor - de canto claro e brilhante - no desempenho de sua função, a saber, a representação do homem tal como o percebia a sua época, o séc. V a.C., devemos recorrer aos textos e a metáforas culturais que nos ajudem a pensar o corpo do homem na ação de um "ator signo." Para tanto, escolhemos um signo dramático (corporal e vocal) que pudesse guiar o ator e o espectador durante o espetáculo. Quem nos deu a idéia foi Ésquilo, ao designar o notável Egisto ${ }^{10}$ por uma metáfora curiosa, o galo. Egisto, o amante de Clitemnestra, personagem que desempenha na tragédia Agamemnon

${ }^{7}$ G. Capone, L'Arte scenica degli attori tragici greci (Padova, Casa Editrice Dott 1935) 19. No passo o autor indica, como o helenista britânico, os mesmos versos de Aristófanes e um escólio a Eurípides para o verso 279 de Orestes.

${ }^{8} \mathrm{~F}$. Paya, De la lettre à la scène, la tragédie grecque (Saussan, L’Entretemps Éditions 2000) 207.

${ }^{9}$ Expressão utilizada por F. Paya, op. cit., 213.

${ }^{10}$ Cf. Odisséia 29: “ [...]. pois recordava-se, no peito, do notável Egisto [...].” 
um papel coadjuvante no assassinato de seu primo, o rei vencedor da guerra de Tróia, é nomeado alektríon.

A linguagem corporal indicada por Ésquilo é polifônica e transmite uma abundância de mensagens. Desse modo o corpo fala em cada movimento e a complexidade da situação instaurada no êxodo é apreendida por uma inteligência prática aplicada à poética do texto. $\mathrm{Na}$ verdade, o corpo de um galo suporta, no texto, a ousadia de Egisto. ${ }^{11}$ Segundo F. Paya, 201:

La parole du corps nous révèle une grammaire complexe [...]". [...] Le corps, support du verbe, nous met face au monde. [...] Même le citadin, coupé de la nature, a un corps qui garde mémoire de la nature. [...] Aucun animal ne peut mimer corporellement ou vocalement d'autres espèces. Un homme peut miauler, rugir, avoir la marche féline et les mouvements saccades de l' insecte. Il peut rouler comme la vague, craquer comme le bourgeon printanier. Issu de la nature, son psychisme a gardé mémoire des violences naturelles.

A alcunha dada ao amante de Clitemnestra nos parece ser materialização de um comportamento não-verbal que se desenvolveu durante todo o drama e, é claro, estamos falando de um corpo fictício, orientado por uma rede de ficções culturais que o movem. Os espectadores experimentam sensorialmente uma projeção de algo que não percebem claramente, visualizando o que Eugenio Barba chama de 'comportamento simbólico'. ${ }^{12}$ "[R] espiro, voz, movimento, palavra. A precisão corporal canaliza a violência trágica [...]". ${ }^{13}$

Mas tal comportamento não seria reservado apenas para a personagem ou o ator trágico que desempenha um hybristés; o poeta cantor, para a execução de suas obras, carecia dos mesmos atributos de um hybristés, é o que postula Marialuigia di Marzio, ${ }^{14} \mathrm{em}$ discussão ao significado dos versos 1-6 do epinício 4 de Baquílides, no artigo intitulado Il gallo di Urania. Nele a autora percorre inúmeras ocorrências

${ }^{11}$ As idéias desse parágrafo estão detalhadamente discutidas no capítulo 3 de F. Paya, op. cit., 191-237.

${ }^{12}$ E. Barba, N. Savarese, A Arte secreta do ator: dicionário de antropologia teatral (São Paulo, Campinas, Editora Hucitec/Unicamp 1995) 18-19 e 186.

${ }^{13}$ F. Paya, op. cit., 205.

${ }^{14}$ M. di Marzio, 'Il gallo di Urania', Quaderni Urbinati di Cultura Classica 76. 1 (2004) 71-89. 
da metáfora para descrever a atividade do poeta. O galo, nuntius vitoriae, é o poeta que canta claro e com voz doce a vitória de um atleta. Para estabelecer uma leitura provável Marzio enumera possíveis associações, no imaginário da Grécia antiga, ao galo. Ele apresentaria como atributos a soberba, a belicosidade, o litígio e o canto. Marzio menciona ainda um episódio famoso (citado também por Winkler) ${ }^{15}$, registrado em Demóstenes 54, 7-9, que relatamos brevemente: na metade do séc. IV, um homem de nome Aríston se põe a perseguir um outro, Conon, acusando-o de hýbris demonstrada após tê-lo derrotado em um combate. A hýbris teria se manifestado da seguinte forma: Conon teria colocado o pé sobre o corpo prostrado de Aríston e dobrando os braços como se fossem asas, nesta postura, cantou, imitando um galo vitorioso.

Assim pensando, nossa meta será limitada; focalizaremos somente esse animal ilustre que figurou em obras literárias de povos do mundo inteiro. Os helênicos, inclusive, foram seus admiradores. Exemplos não faltam.

Recordemos a cena esquiliana já citada: coro, Clitemnestra e Egisto, no final do drama, todos disputam com agressões verbais, até que o coro dos respeitáveis cidadãos de Argos ironiza (Agamémnon 1671): "Canta! Sê corajoso como um galo ao lado da sua fêmea." A frase deve ter provocado efeito, pois serve, anos mais tarde, a Aristófanes que, pela boca de Eurípides, critica, em Rãs 935, o velho Ésquilo: "Mas era preciso poetar até um galo nas tragédias?"

Era. O galo é, com sua crista e rabo, um animal elegante, símbolo de coragem e derrisão. J. Dumont ${ }^{16}$ aponta, para ele, uma origem indiana, depois persa, depois egípcia. Frequentemente oferecido em sacrifícios rituais - recordemos da exortação, ainda obscura, ${ }^{17}$ de Sócrates para Críton no Fédon (118a) -, a ave ora aparece como um psychopompós, ora vive, domesticada, no meio das gentes ricas e pobres. Para associá-la ao espetáculo trágico, focalizamos principalmente seu canto claro, solitário e brilhante e sua teatralidade para andar. Qualquer exemplar dessa espécie tem uma "agressividade automática" no interior de sua própria família - relembramos Aristóteles na Poética que instrui (1453b 20) o poeta a

${ }^{15}$ J.J. Winkler, 'Laying down the law: the oversight of men's sexual behavior in classical Athens', in D. Halperin, J. Winkler, F. Zeitlin (eds), Before Sexuality (Princeton, New Jersey 1990) 181.

16 'Les combats de coq furent-ils un sport?', Pallas 34 (1988) 33-44.

${ }^{17}$ G. W. Most, ‘A cock for Asclepius', Classical Quarterly 43 (1993) 96-11. 
se utilizar de ações criminosas que se passem em família. Os galos, em rinhas, coreografam um balé rápido, intrépido, arrogante e ordenado; na verdade, combatem por instinto, combatem por galinhas, combatem por poder. J. Dumont vê neles uma ligação com os heróis homéricos combatentes. Concordamos com o helenista: esse animal, de fato, parece colocar em cena o combate até a exaustão; entretanto propomos que sua desmedida é mais trágica que épica e que ele pode servir de modelo para uma tradução da postura trágica no corpo do ator contemporâneo.

Daremberg e Saglio, no Dictionnaire des Antiquités Grecques et Romaines (alektryónon agônes) informam que os gregos antigos eram 'apaixonados' por brigas de galo. No momento da luta, os animais, armados com um esporão de bronze, eram colocados em uma espécie de arena com bordas elevadas (telía). Segundo os estudiosos, em Atenas, uma vez por ano, uma rinha de galos acontecia no espaço do teatro e os jovens deviam assistir a esse espetáculo para aprender a resistir até o fim (Luciano, De gymn. 37; Platão, Leis 789b); ainda segundo os mesmos autores, no teatro de Dioniso em Atenas, figurava, de cada lado, uma entidade alada, ${ }^{18}$ colocando dois galos em combate, dado que nos parece importante para relacioná-los com a persona trágica.

Mas retornemos ao texto dramático. Aristófanes oferece-nos um outro verso bastante útil para pensarmos a relação homem-galo. Em Nuvens 1428-1429, Fidípides exorta: "Observa os galos e as outras bestas aqui, da mesma forma se vingam dos pais... aqueles, sem dúvida, destoam de nós, mas só porque não escrevem deliberações." O fato de o poeta ligar, claramente, o homem e o galo é elucidativo para nossa abordagem. Píndaro, Olímpica 12. 14, procede da mesma forma e recorda que o filho de Filanor, se não houvesse combatido nos Jogos Olímpicos, seria como um galo que, sem fama, luta escondido em um quintal. Tomemos a consultoria de Píndaro: por ele, o homem se assemelha a um galo, que combate para ser, gloriosamente, admirado. Nesse sentido, o combate é um espetáculo.

A soberba do galo está registrada ainda na fábula de Esopo, $O$ galo e a águia: dois galos brigam por uma galinha. $\mathrm{O}$ vencedor, eufórico, sobe no muro e se põe a cantar, porém uma águia que passa arrebata-o. O derrotado, depois disso, torna-se senhor absoluto. Nessa situação, rimos ou choramos?

Se recuperamos, mais uma vez, a Oréstia de Ésquilo, Egisto, galo vitorioso na primeira peça, será derrotado por Orestes em Coéforas que,

${ }^{18}$ J. Dumont, op. cit., 37, fala de uma encarnação do deus Agôn. 
arrebatado pelas Erínias, só alcançará descanso com a intervenção de Atena. Ainda o mesmo Ésquilo, em Eumênides 858-861, pelas palavras de Atena, proíbe as Erínias de implantarem no peito dos jovens os aguilhões sangrentos de vingança que trazem os corações dos galos. Tratar-se-ia de galos de rinha ou de homens trágicos que disputam entre si o poder e a glória?

Há ainda outra história de galo nas fábulas de Esopo: um fazendeiro compra uma perdiz e leva-a para seu galinheiro. A pobre ave é atacada de imediato pelos galos e, por isso, sente-se rejeitada e reflete: "talvez seja porque pertenço a uma outra raça". Entretanto, pouco tempo depois, a perdiz verifica que os mesmos galos que contra ela investiram põemse a lutar e a ferir-se mutuamente. Ao vê-los ensangüentados, a perdiz entende sua índole guerreira. ${ }^{19}$

Não é só a índole guerreira que distingue o galo. A ave é símbolo do ardor amoroso incontrolável (aphrodisiastikón), como afirma Dumont (op. cit., 37-38):

L'oiseau symbolise donc l'ardeur amoureuse, dont l'agressivité est la simple conséquence; il est le présent de l'éraste à l'éromène.

[...]

La sexualité débridée du coq tient cependant à d'infimes réactions biochimiques induites par un fragment de gene d'un de ses chromosomes. Qu' un dérèglement hormonal se produise, ce que n'est pas rare, et l'animal change de sexe.

Com certeza, um galo sozinho comanda todo um galinheiro. Galo derrotado não canta, mas o vitorioso, ao contrário, estufa o peito, bate as asas e solta sua voz para o mundo em gargalhada sonora. Aristóteles menciona o fato na História dos Animais 536a. Em Aves 483-485, citando novamente o comediógrafo, Aristófanes conta a história desse bicho-homem: o galo foi senhor dos persas e comandou este povo antes de todos os Darios e Megabazos; por isso, desfila ainda hoje com seu gorrinho empinado sobre a cabeça e dá ordens ao sol.

Nosso amigo, no seu percurso literário, foi também protagonista em $O$ galo, de Luciano (cf. § 3). Micilo conta que a raça surgiu por causa da ira de Ares contra um tal Alectrion, um amigo do deus, que participava com ele em banquetes e festins. O rapaz ficava sempre à porta da casa de Hefesto, na função de sentinela, vigiando, regularmente, nos encontros

${ }^{19}$ Com referência à índole combativa do galo: Aristófanes, Aves 71. 
amorosos de Ares com Afrodite, o retorno do deus coxo para sua casa. À chegada do sol, que tudo vê, Alectrion cantava alto, anunciando a luz e, com ela, o marido traído, Hefesto. Um dia, contudo, sucedeu que o jovem adormeceu. $\mathrm{O}$ sol iluminou o leito em que dormiam Afrodite e Ares e expôs os seus amores ilícitos. Ares, enfurecido, transformou Alectrion, com armas e tudo, em galo. Seu elmo vermelho sobre a testa comprova, nos nossos dias, a triste sina do rapaz. O opúsculo luciânico é interessante para nós, porque o escritor dá voz ao bicho, que discorda da história de Micilo e narra que sua transformação teria sido mais recente e graças a múltiplas reencarnações: foi Euforbo, o guerreiro troiano que, cheio de jactância, desafiou o poderoso Menelau; o filósofo e matemático Pitágoras; depois Aspásia, a hetaira de Mileto e amante de Péricles e, finalmente, Crates de Tebas.

Assim, embora nem todos os gregos estejam de acordo (Luciano, no seu opúsculo $O$ Galo, é um exemplo), o cantar do animal, à noite, é agradável e útil, pois marca inteligentemente o passar do tempo, acorda o sonolento, encoraja o desanimado, conforta o caminheiro. Ao glorioso cantar do galo, o ladrão abandona seu ofício, a estrela da manhã acorda, levanta-se e brilha no céu. É interessante pensarmos que a estrela da manhã é Vênus e que ela surge no céu com o cantar do galo. Não deixa de ser uma bela metáfora, porque sugere que ela, a antiga Afrodite, se ergue do leito, quem sabe, trêmula, e abandona Ares, para no céu brilhar solitária.

Nesse ponto de reflexão, afirmamos que uma característica comum entre o galo e o homem é, portanto, a arrogância a qual, no contexto trágico, pode ser, por nossa argumentação, entendida como hýbris, desmedida.

Não há figura mais trágica que esse pobre dos deuses. O Bestiário de Aberdeen informa que o galo, em latim, gallus, recebeu seu nome do ato de castração: somente ele, entre todas as aves, teve seus testículos retirados. Somente ele tem sua potência cerceada. Os antigos chamavam os homens castrados, os eunucos, de galli. Os sacerdotes de Cibele também levavam esse nome.

Se um galo pode muito no seu terreiro, Gallus in suo sterquilinio plurimum potest (Sêneca, Apokolocyntosis 7,3 ) é lá que, para se sentir seguro, deve viver só, sem concorrentes (e esse é um grande obstáculo, segundo Aristóteles, Política 1253a, 27ss., para a eudaimonía, a felicidade.

De gorrinho na testa, cabeça empinada, passo de general, o galo, arguto, do poleiro, vê tudo, anuncia a alvorada e dá o toque de recolher. 
Os compositores Lamartine Babo e Paulo Barbosa sabiam disso quando prestigiaram o galinho nervoso. Figurinha difícil e trágica, ser de sofrimento, de solidão e de desmedida, conforme aprendemos na Marchinha do Grande Galo (domínio público):

O galo de noite cantou/ Toda gente quis ver/O que aconteceu/Nervoso, o galinho respondeu: có, có...ro /A galinha morreu!/

có, co..., ro/ O galo tem saudade/Da galinha carijó!/ A minha vizinha também/ Certa noite gritou/Toda gente acordou/Nervoso, o marido respondeu:/ có, có, ... ro/ Hoje o galo sou eu!

Mas como diz o provérbio, Nem sempre galinha, nem sempre galo. Os aspectos da marchinha que queremos realçar são dois: o lamento do galo que se vê só e a retomada do poder pelo marido subjugado: Hoje o galo sou eu! Enfim, o marido-galo volta a ser o símbolo do macho dominador. Pontifica a sabedoria popular: cada galo canta no seu poleiro, e o bom, no seu e no alheio; e um galo no seu poleiro briga com o mundo inteiro.

Não obstante, retomemos nosso propósito inicial, refletir sobre o ator trágico e discutir uma possível postura para ele. Quando propomos essa questão, estamos de fato questionando pressupostos teóricos mais profundos. Desde Platão, no Banquete (223d), e Aristóteles na Poética, ${ }^{20}$ polemiza-se acerca do assunto, a saber, o éthos de um poeta trágico. Admite-se para os poetas (também atores no mundo antigo) que compõem tragédias um estufar de peito e cantar magnífica e gravemente uma história. Entretanto, a gravidade exagerada, a desmedida, por vezes acaba caindo no ridículo e nada mais triste, lamentável, vulgar e de zombaria que um galo perdedor. Dumont $^{21}$ nos indica a situação dramática, o impasse trágico do galo no espaço cênico:

Les coqs vont incarner le génie même des combats, le dieu Agôn, représenté sur les bras du trône du grand-prêtre au théâtre de Dionysos. L'assimilation au combat humain se poursuit dans le vocabulaire: l'oiseau vaincu était réduit en esclavage, douleia. Il se taît alors que le vainqueur chante.

${ }^{20}$ Aristóteles define o gênero poético pelo éthos do poeta, cf. Poética, 1448b, $20-25$.

${ }^{21}$ Op. cit., 37.

Faculdade de Letras | Universidade de Coimbra 
Existem inúmeras teorias para definir o que é uma tragédia grega; parece-nos, contudo, que nenhuma delas é satisfatória. Não vamos abordar o tema. Tomemos por consenso que a tragédia manifesta uma tendência para contemplar o excesso, a desmedida, a hýbris que nos acomete quando ousamos combater e vencer o inexorável. Essa postura se liga muito àquela do galo que comentamos. Elegante enquanto vencedor, ridículo enquanto cantador vitorioso abatido.

A hýbris por ela mesma nada diz. O movimento em direção ao extremo, ao ponto último de dignidade, o qual, por descuido, o vencedor, embevecido consigo mesmo, ultrapassa limites e sob o olhar de um deus implacável - ou de uma águia ou mesmo de um gavião que vem do alto - torna-se exemplo para toda a pólis: a punição virá tal como informa Hesíodo na fábula do rouxinol..$^{22}$ Desgraçados e insensatos somos, quando com os mais fortes queremos nos medir. Desse modo, pelo "desgraçados", somos trágicos; pelo "insensatos", tragicamente tolos e ridículos.

Todavia, ao postularmos que os homens trágicos são como galos de rinha, fanfarrões cheios de vaidade e desmedida não estamos pesando somente no galo vencedor. F. S. Halliwell ${ }^{23}$, outra vez a partir do conhecido discurso de Demóstenes Contra Conon, afirma ser a hýbris uma postura cênica de arrogância zombeteira. Segundo Halliwell, Conon utilizou-a fora do espaço cênico, em litígio real, ou seja, ele tomou a postura do agressor que ri, zomba e escarnece no cotidiano da pólis. O cantar e bater vigoroso de asas seria, para o helenista, a materialização gestual e sonora da hýbris do vencedor triunfante.

Mas o homem trágico, sendo um inveterado apórico, divide-se. Ele ri do inimigo e é refém atormentado do riso dos outros. "É que não se pode tolerar que os inimigos escarneçam de nós [...]". ${ }^{24} \mathrm{O}$ ato de rir, portanto, oscila entre a celebração da vida e a ostentação do culto ao antagonismo. É expressão de liberação e alegria e, ao mesmo tempo, manifestação de ódio e execração. Observem a atitude de Medeia: "Ninguém me suponha fraca e débil, nem sossegada; outro é meu

${ }^{22}$ Inevitável referir que a águia é o animal-símbolo do grande Zeus. Cf. Hesíodo, Trabalhos e Dias 201-213.

23 'The uses of laughter in Greek culture', Classical Quarterly 41(1991) 279-296.

${ }^{24}$ Eurípides, Medeia 797, em tradução de Maria Helena da Rocha Pereira. 
caráter: dura para os inimigos, benévola para os amigos." ${ }^{25} \mathrm{E}$ fazer o mal inclui rir, ultrajar, zombar e escarnecer. ${ }^{26}$

A atitude de rir envolve, na língua grega, um vocabulário amplo ${ }^{27}$ que tenta abranger várias nuanças e práticas culturais, as quais podem variar de um riso simples e pueril (paízein) até um riso virulento e perigoso (loidoreîn). Todavia, como sói acontecer no terreno da linguagem, um mesmo verbo pode ser usado de maneira positiva ou negativa, visto que a ambigüidade do ato de rir - essencial à tragédia enquanto fruto da sofística - ocorre tanto no ato quanto na fala. C. Miralles ${ }^{28}$ analisa a proximidade semântica existente entre termos do léxico de rir com termos correlatos ao conceito hýbris. Ele cita: gelân (rir, fazer brilhar a face com os dentes), chaírein (alegrar-se), oneidizeîn (censurar), ekxonidízein (censurar com injúrias), epaúchein (exultar), gegethós (exultante), thállon (florescente); segundo o helenista, em todos os casos mencionados encontramos a idéia de alargamento, exuberância, preenchimento e excesso.

Nem vencedores, nem vencidos: a postura do galo, na tragédia grega, permite ao ator sugerir presunção na vitória e, ao mesmo tempo, como na fábula hesiódica, autoriza o espectador a prever a punição; afinal, o canto para expressar um triunfo frente a um oponente derrotado pode ser muito fugaz. Este riso que imputa à vítima a vergonha (o riso sugerido por Atena e rechaçado por Ulisses ${ }^{29}$ ) é expressão orgânica de uma sociedade em permanente stásei (desacordo). Nesse contexto, vilipendiar pode ser tanto um ato positivo - força real capaz de manter valores e corrigir desvios - quanto destruidor, isto é, uma arma natural para perseguir os inimigos até mesmo depois da morte.

Concluindo: sabemos que existem inúmeras anedotas sobre os atores antigos e que elas surgiram, provavelmente, por causa de serem eles

${ }^{25}$ Eurípides, Medeia 807-809, em tradução de Maria Helena da Rocha Pereira.

${ }^{26}$ Cf. Knox, op. cit., 12, 128, 153. Knox cita Arquíloco, Sólon, Teógnis, Píndaro e Simônides e sugere a alteração da conduta - por motivos diversos - a partir do platonismo e cristianismo.

27 Paízo (divertir, brincar), okópto (zombar), bomolocheúomai (fazer-se de bufão, de palhaço), totházô (fazer troça, caçoar, desprezar), kataguelô (rir de), gelô (rir), aischroepô (dizer tolices, obscenidades), loidorô (escarnecer, insultar, ultrajar), kacharázo (gargalhar), meidiô (sorrir), saíro (mostrar os dentes) etc.

28 'Le rire chez Sophocle', in M-L. Desclos (org.), Le rire des Grecs (Grenoble, Ed. Jérôme Millon 2000) 413-418 e 420.

${ }^{29}$ Sófocles, Ájax 79. Cf. F. S. Halliwell, op. cit., 279-296. 
excessivamente miméticos, alusão já apontada por Aristóteles (Poética 1462a). É provável que tais anedotas façam referência à emergência de um estilo mais realista (embora o que possa parecer natural e realista para uns, para outros, pareça artificial e convencional). ${ }^{30}$ Os atores, no entanto, sabem medir seus excessos (se não sabem o público sinaliza seus erros e acertos). Um bom ator é capaz de ler um texto e retirar dele a postura ideal para cada personagem. Nossa sugestão para corporificar, na atuação do personagem trágico, um galo é apenas uma das inúmeras possibilidades. Os textos de Ésquilo, Sófocles, Eurípides e Aristófanes foram nossos guias, tudo que afirmamos está sugerido nos textos.

\section{Bibliografia}

J. Austin, Quando dizer é fazer (Porto Alegre, Artes Médicas 1990).

D. Bain, Actors and Audience: a study of asides and related conventions in Greek drama (Oxford University Press 1977).

E.Barba e N. Savarese, A arte secreta do ator: dicionário de antropologia teatral (São Paulo/Campinas, Editora Hucitec/Unicamp, 1995).

T. V. R Barbosa e C. F Lage, 'O riso obsceno no êxodo de Agamemnon de Ésquilo', Scripta Classica on-line. 2. (2006) 58-75. http://www. geocities.com/scriptaclassicaonline/index.htm

C. Benedetti (ed.), Esopo Favole (Milano, Arnaldo Mondadori Editore 1996).

G. Capone, L'arte scenica degli attori tragici greci (Padova, Casa Editrice Dott 1935).

D. del. Corno, Eschilo Agamennone, Coefore, Eumenide (Milano, Arnaldo Mondadori Editore 1995).

C. Consonni (ed./trad.), Luciano Il sogno, Il gallo, L'asino (Milano, Arnoldo Mondadori Editore 1994).

J. Daremberg e A. Saglio, Le Dictionnaire des Antiquités Grecques et Romaines.

http://dagr.univtlse2.fr/sdx/dagr/images/t1_p1_jpg_hq/t1_p1_dagr_ page_192_image_0001.jpg

M.-L. Desclos (org.), Le rire des Grecs (Grenoble, Ed. Jérôme Millon 2000).

${ }^{30} \mathrm{D}$. Bain, Actors and Audience: a study of asides and related conventions in Greek drama (Oxford University Press 1977) 7.

Faculdade de Letras | Universidade de Coimbra 
J. Dumont, 'Les combats de coq furent-ils un sport?', Pallas 34 (1988) 33-44.

A. Esclasans (trad.), Píndaro Himnos Triunfales (Barcelona, Editorial Iberia 1987).

J. Farrel, "Classical Genre in Theory and Practice', New Literary History 34 (2003) 383-408.

G. P. Goold (ed.), Hesiodo, The Homeric hymns and homerica (London, Harvard University Press 1982).

F. S. Halliwell, 'The uses of laughter in Greek culture', Classical Quarterly 41 (1991) 279-296.

B. Knox, Word and action - Essays on the Ancient Theater (Baltimore/ London, The Johns Hopkins University Press 1986).

S. Kampff Lages, Walter Benjamin. A tarefa-renúncia do tradutor www. letras.ufmg.br/site/publicacoes/.../tarefadotradutor-site.pdf

D. W. Lucas (ed.), Poetics (Oxford, Clarendon Press, 1968).

D. Lateiner, Sardonic Smile (Ann Arbor, University of Michigan Press 2001).

E. V. Maltese (trad.), Platone, tutte le opere (Roma, Grandi Tascabili Economici, 1997).

M. di Marzio, 'Il gallo di Urania', Quaderni Urbinati di Cultura Classica 76. 1 (2004) 71-89.

C. Miralles, 'Le rire chez Sophocle', in M-L. Desclos (org.), Le rire des Grecs (Grenoble, Ed. Jérôme Millon 2000) 407-424.

G. W. Most, Hesiod: Theogony, Works and Days, Testimonia (Cambridge, MA Harvard University Press 2006).

G. W. Most, 'A cock for Asclepius', Classical Quarterly 43 (1993) 96111.

R. Mugellesi (trad.), Seneca Apocolocyntosis (Milano, Rizzoli Libri S.p.A 2000).

D. Norman, Birds and beasts of the Greek anthology http://bestiary. ca/etexts/collins 1913/symbolism\%20of\%20animals\%20and\%20 birds $\% 20 \% 20$ collins $\% 20-\% 20$ text.pdf

E. D. Palmeira (trad.), Tragédias do ciclo troiano - Ájax, Electra, Filoctetes (Lisboa, Livraria Sá da Costa Editora 1973).

F. Paya, De la lettre à la scène, la tragédie grecque (Saussan, L'Entretemps Éditions 2000).

A. Philippon (ed./trad.), Plutarque, I. Comment lire les poètes (Paris, Les Belles Lettres 1987).

R. Picnarre (trad.), Théâtre de Sophocle, 2. (Paris, Libraire Garnier Frères 1947).

Faculdade de Letras | Universidade de Coimbra 
A. W. Pickard-Cambridge, The dramatic festivals of Athens (Oxford, Clarendon Press 1968).

M. H. Rocha Pereira (trad.), Eurípides Medeia (Lisboa, Calouste Gulbenkian 2005).

T. J. Saunders (trad.), Aristotle Politics I-II (Oxford University Press 1996).

M. T. Schiappa de Azevedo (trad.), Platão Banquete (Lisboa, Edições 70 1991).

A. Seisdedos, 'Significación y desarrollo de las metáforas de animales em Eurípides', Helmantica 110 (1985) 277-293.

M. F. Silva (trad.), Aristóteles. História dos animais http://www. obrasdearistoteles.net/index.php?option=com_volumes

A. H. Sommerstein (ed.), Aeschylus Eumenides (Cambridge, University Press 2004).

W. B. Stanford (ed.), Aristophanes, The frogs (London, New York, Macmillan \& Co. Ltd. 1963).

A. M. Valente (trad.), Aristóteles. Poética (Lisboa, Calouste Gulbenkian 2007).

A. Varandas, A cabra e o bode nos Bestiários Medievais ingleses. http:// www.brathair.com

J. J. Winkler, 'Laying down the law: the oversight of men's sexual behavior in classical Athens', in D. Halperin, J. Winkler, F. Zeitlin (eds), Before Sexuality (Princeton University Press 1990) 171209.

J.Wise, 'Tragedy as an augury of a Happy Life', Arethusa 41 (2008) 381-410.

The Aberdeen Bestiary. In: http://www.abdn.ac.uk/bestiary/translat/38v. hti

Latin Bestiary. In: http://bestiary.ca/beasts/beast258.htm Acesso em 09/06/07. 